\title{
ARMAZENAMENTO DE SANGUE DE CORDÃO UMBILICAL E PLACENTA: PÚBLICO, PRIVADO OU AMBOS?
}

Existem poucas dúvidas sobre as vantagens de se dispor de células-tronco com o armazenamento de sangue de cordão umbilical e placenta (SCUP) colhido no momento do parto. $\mathrm{O}$ que se questiona é: deve ser público ou privado?

O SCUP rico em células-tronco hematopoiéticas (CTH), é coletado no parto, cesariano ou vaginal, sem risco adicional para o recém-nascido doador. Antes do seu armazenamento é processado, tipado para os antígenos leucocitários humanos (HLA) e crio-preservado. Quando se compara com o material obtido da medula óssea, apresenta menor risco de contaminação viral, menor necessidade de compatibilidade HLA, menor incidência de doença enxerto-hospedeiro aguda e crônica e, se ocorrer, tende a ser menos grave. Portanto, ele tem seu lugar garantido no arsenal terapêutico médico. Algumas indicações para o uso terapêutico das células-tronco são: portadores de doenças malignas e aplásticas da medula óssea, doenças metabólicas hereditárias e imunológicas e após uma mielo ablação. Até o momento atual, outras indicações para o uso terapêutico do SCUP são especulativas e é prematuro imaginar que haja benefícios no tratamento de doenças degenerativas. Pelo menos 6.000 unidades foram utilizadas para transplante; a grande maioria oriunda de bancos públicos ou de organizações privadas sem fins lucrativos (Netcord Foundation e Bone Marrow Donors Worldwide). Existem, hoje, ao redor de 300.000 unidades de SCUP armazenadas no mundo.

O armazenamento do SCUP em banco privado direciona-se ao transplante autólogo, isto é, em benefício exclusivo do próprio doador (normas da Anvisa). O banco público fornece SCUP para o transplante alogênico, utilizando o material dos doadores voluntários, constituído por grande número de amostras.

Existe grande distinção entre banco privado (autólogo) e banco público (alogênico) quanto às indicações de terapêutica com SCUP. O transplante autólogo se limita a receptores de até 40-50 Kg, fazendo uso de sua única amostra armazenada. Não se cogita o emprego do transplante autólogo em doenças congênitas, uma vez que todas as células do paciente apresentam o mesmo genoma, exceto se, no futuro, se concretizar o desenvolvimento de terapia gênica. Nesse sentido, alguns estudos mostram que certas leucemias podem ter início intrauterino, manifestando-se posteriormente. Nesses casos o transplante autólogo não é a primeira escolha. Da mesma forma, o uso de transplante autólogo em linfomas e doenças autoimunes é limitado pela pequena quantidade de $\mathrm{CTH}$ na unidade armazenada, suficientes somente para transplante em crianças e não em adultos. Além disso, em crianças com tumores sólidos, o transplante autólogo não é uma opção terapêutica padrão, exceto no neuroblastoma fase IV, patologia rara. Porém, é limitado pela insuficiência de células para os ciclos necessários de tratamento. A solução é a expansão das CTH armazenadas, procedimento ainda não adotado na prática clínica. Por isso, menos de $5 \%$ dos transplantes em pediatria são autólogos. Por outro lado, a chance de o doador desenvolver doença passível de tratamento por essas células, até a idade de 20 anos, é de 1:10.000 a 1:200.000.

No transplante alogênico, ao contrário do autólogo, podese utilizar mais de uma unidade de SCUP compatível armazenada possibilitado pelo número disponível de amostras. Sem o inconveniente de carrear os mesmos erros congênitos (autólogo), o transplante alogênico substitui as células da medula óssea doente por um enxerto, permitindo nova hematopoiese e novo sistema imune. Em consequência disso, auxilia na erradicação de células sobreviventes ao tratamento pré-enxerto, no caso de doenças malignas. Nestas, o armazenamento autólogo e sua utilização são controversos, pois, se essa doença se apresentar no futuro, pode-se utilizar CTH mobilizadas e coletadas por aférese do próprio paciente.

Quanto à plasticidade das CTH de SCUP, pode-se afirmar que outras células presentes na criança (medula óssea, polpa dos dentes deciduais) ou no adulto, também podem possuir a mesma característica, e que tanto quanto a primeira, estudos futuros poderão viabilizá-las. Estudos de desdiferenciação e o progresso nos estudos de tolerância imunológica poderão tornar realidade o uso de células do próprio paciente para o tratamento de doenças, sem necessidade de armazenamento.

O uso do SCUP armazenado por banco privado no Brasil é permitido somente ao doador, sendo vetado o uso pelos familiares, segundo norma da Anvisa, embora já tenha ocorrido autorização judicial extraordinária para essa finalidade. Quanto ao ônus financeiro para o armazenamento autólogo, cálculos dão conta que o valor despendido, em média, é igual ou superior ao investido no mercado financeiro e sacado no futuro, numa eventual necessidade, para procura de compatibilidade nos registros disponíveis.

A tendência de armazenamento, no mundo, recai para o público (doação voluntária). Existem propostas diferentes, como o armazenamento misto, privado, até um período previamente ajustado e, posteriormente, liberado à doação. Isso se justifica, com respaldo da literatura, pela persistência do potencial de tratamento das unidades crio-preservadas (amostras mais antigas datam de 20 anos). Mesmo nos Estados Unidos, que concentra o maior número de unidades em bancos privados, a tendência é o crescimento do público. Por ato do governo, no final de 2005, destinou-se 79 milhões de dólares para que o New York Blood Center, o maior banco público do mundo, aumentasse em I 50.000 amostras o seu acervo, para 
atingir $90 \%$ de chance de compatibilidade no registro americano. Nos países da Comunidade Européia, o armazenamento de SCUP, na grande maioria é realizado por bancos públicos acreditados, com regras comuns para os participantes. $O$ armazenamento privado é proibido em muitos países, só podendo ser realizado em clínica privada, mediante consentimento informado.

No Brasil permite-se o armazenamento privado, regulado pela Anvisa, com vários bancos em funcionamento. Existe também um sistema de armazenamento público, o BRASILCORD, em fase de estruturação para se associar ao NETCORD (rede mundial de bancos públicos), o que poderá possibilitar o intercâmbio de unidades. O banco público brasileiro, inaugurado em 2001, dispõe de 6000 unidades armazenadas, tendo utilizado 50 unidades para transplante. Um acervo ainda pequeno para as nossas reais necessidades.

As justificativas científicas a favor do armazenamento público não invalidam, hoje, a opção da família pelo privado (embora com muitos questionamentos éticos), quando houver pequena possibilidade de armazenamento em banco público. Isso tem apoio em recentes trabalhos que demonstram a multipotencialidade das células mesenquimais do SCUP e expansibilidade in vitro das $\mathrm{CTH}$, ainda que limitada, mas que amplia sua utilização em adultos. Condições essenciais para essa opção é a disponibilidade de recursos financeiros próprios para fazer esse armazenamento, além de orientação autônoma (não vinculadas aos bancos privados) quanto às reais condições de utilização futura do sangue de cordão umbilical armazenado. Outras questões importantes quanto ao funcionamento do banco privado dizem respeito ao suporte financeiro para assegurar a viabilidade futura da unidade armazenada (quem se responsabilizaria pela manutenção das amostras se o banco de SCUP falir?). Normas rigorosas de controle de todo o processo devem ser obedecidas, semelhantes aos bancos públicos. Essas normas, que abrangem o controle de qualidade e padronização, classificação e rastreabilidade da amostra, devem ser complementadas por legislação rígida para restringir a publicidade irregular ou mesmo os apelos comerciais como o "momento único para a coleta". Por vezes, o ato é apresentado, de maneira sedutora, como um "seguro biológico para a saúde do filho", gerador de ansiedade aos pais, quanto ao bem-estar futuro do seu filho, quando eles não armazenam o SCUP por ser oneroso. Ademais, a divulgação inapropriada deve ser coibida (por exemplo, em consultórios e maternidades). A coaptação da equipe obstétrica, na indicação do procedimento e na coleta do material, oferecendo vantagens financeiras, deve ser combatida.

Os bancos privados se esforçam em atender a demanda por armazenamento de SCUP, porém pelo exposto acima, como nos países desenvolvidos, o caminho único e viável, no Brasil, além do esclarecimento efetivo dos pais, é a expansão da capacidade de armazenamento público de SCUP para atender a demanda de considerável segmento da população, ainda sem alternativas concretas para o transplante alogênico.

Sergio Duarte

Pesquisador doutorando do Departamento de Obstetrícia e Ginecologia da FMUSP, São Paulo, SP

Seizo Miyadahira

Livre-docente do Departamento de Obstetrícia e Ginecologia da FMUSP, São Paulo, SP

Marcelo Zugaib

Professor titular do Departamento de Obstetrícia e Ginecologia da FMUSP, São Paulo, SP

Referências

I. Warwick R, Armitage S. Cord blood banking. Best Pract Res Clin Obstet Gynaecol. 2004; | 8(6):995- 101 I .

2. Cord blood registries. Bone Marrow Donors Worldwide (BMDW). [cited 2008 jul 30]. Available from: http://www.bmdw.org/index.php? id = statistics_cordblood.

3. Fisk NM, Roberts IA, Markwald R, Mironov V. Can routine commercial cord blood banking be scientifically and ethically justified? PLoS Med. 2005;2(2):e44. 4. Barker JN, Wagner JE. Umbilical cord blood transplantation: current practice and future innovations. Crit Rev Oncol Hematol. 2003;48(I):35-43.

5. Tse W, Bunting KD, Laughlin MJ. New insights into cord blood stem cell transplantation. Curr Opin Hematol. 2008; 15(4):279-84.

6. Dalle JH. Cord blood banking: public versus private banks — facts to ponder and consider. Arch Pediatr. 2005; I 2(3):298-304.

7. Annas GJ. Waste and longing - the legal status of placental-blood banking. N Engl ] Med. 1999;340(19): 1521-4. 